Received: 10 March 2021

Accepted: 17 March 2021

Published: 30 Juni 2021

\title{
Kepentingan Negara-Negara Arab (Uni Emirat Arab, Bahrain, Sudan dan Maroko) Melakukan Normalisasi Hubungan dengan Israel
}

\author{
Yulia Rimapradesi \\ Afiliasi Universitas Muhammadiyah Yogyakarta \\ Email: yuliarimapradesiumy@gmail.com \\ Ahmad Sahide \\ Afiliasi Universitas Muhammadiyah Yogyakarta \\ Email: ahmadsahideumy@gmail.com
}

\begin{abstract}
Arab states and Israel has for decades had dividing wall for diplomatic relations. The existence of ideological differences between Islam and Judaism as well as a long history of colonialism and conflict makes it difficult to unravel the conflict between of them. However, this seems to change, towards the end of 2020 with the encouragement of Donald Trump as president of the United States. Arab countries seem to forgot the events of the past and break up the wall that previously served as a barrier between them and Israel. The United Arab Emirates, Bahrain, Sudan and Morocco has reasons what they thinks are rationality that their initial stance in favor of Palestinian independence seems to be waning. This paper discuss about the interests of the Arab states in the the normalization of their relationship with Israel. The research method in this paper is qualitative method with inductive analysis with the latest data from various document sources as material for analysis. This paper concludes the interests of the United Arab Emirates, Bahrain, Sudan and Morocco are dominated by security and the economy for their countries.
\end{abstract}

Keywords: Normalization, Israel, Arab States, Palestine, and AS

\begin{abstract}
Abstrak
Negara-negara Arab dan Israel selama puluhan tahun memiliki tembok pembatas untuk hubungan diplomatik. Adanya perbedaan ideologi antara Islam dan Yahudi serta sejarah kolonialisme dan konflik yang panjang membuat kerumitan untuk mengurai konflik diantara mereka. Namun hal tersebut seolah berubah, menjelang akhir tahun 2020 dengan dorongan Donald Trump sebagai presiden Amerika Serikat. Negara-negara Arab seolah melupakan kejadian-kejadian di masa lalu dan melerai tembok yang sebelumnya menjadi pembatas antara mereka dan Israel. Uni Emirat Arab, Bahrain, Sudan dan Maroko memiliki alasan yang menurut mereka begitu rasional sehingga pendirian awal mereka mendukung kemerdekaan Palestina seperti memudar. Pada tulisan ini membahas tentang apa sebetulnya yang menjadi kepentingan-kepentingan negara Arab atas normalisasi hungan mereka dengan Israel. Metode penelitian pada tulisan ini merupakan metode kualitatif dengan analisa induktif dengan datadata terbaru dari berbagai sumber dokumen sebagai bahan analisa. Tulisan ini berkesimpulan bahwa kepentingan Uni Emirat Arab, Bahrain, Sudan dan Maroko didominasi atas keamanan dan ekonomi bagi negara mereka.
\end{abstract}

Kata kunci: Normalisasi, Israel, Negara-negara Arab, Palestina dan AS. 


\section{Latar Belakang Masalah}

Hubungan negara-negara Arab dengan Israel sebelumnya dibatasi oleh tembok secara tak kasat mata. Adanya faktor perbedaan ideologi antara Islam dan Yahudi serta sejarah kolonialisme terdahulu menjadikan pemetaan konflik antara Islam dan Yahudi di Timur Tengah ini belum juga usai. Sebagian besar negara-negara Arab ini tergabung dalam organisasi regional yaitu Liga Arab (Bixby, 1992). Liga Arab sebagai organisasi regional yang mewakili kepentingan orang-orang Arab didirikan pada 22 Maret tahun 1945. Liga Arab Ini didirikan untuk menentang ekspansionisme kolonial pasca-Perang Dunia II, untuk memainkan peran aktif dalam perjuangan melawan negara Yahudi di Palestina, mempererat hubungan negara-negara kawasan Arab dan sebagian Afrika, serta membangun kerja sama di bidang ekonomi, politik dan militer (Coskun, 2020).

Keinginan untuk merdeka secara berdaulat dari Palestina telah menjadi perjalanan yang panjang, apalagi ketika 1948 Israel merdeka secara berdaulat. Dua isu yang mendorong konflik antara Israel dan Palestina sebenarnya adalah tentang hak Palestina untuk bisa mendirikan sebuah negara di tanahnya sendiri dan Israel menginginkan wilayah negara sesuai dengan keinginannya dan bisa hidup damai berdampingan dengan negara Arab lainnya (Bandoro, 1991). Keterlibatan negaranegara Arab sebagai anggota Liga Arab terhadap perjuangan kemerdekaan Palestina telah berlangsung lama. Mulai dengan adanya invansi ke Palestina pada 15 Mei 1948 setelah terbentuknya negara Israel pada 14 Mei 1948 (Masyrofah, 2015). Alasan pemerintah Negara Arab melakukan hal tersebut diantaranya, bahwa pemerintahan Palestina harus dikembalikan kepada penduduknya, sesuai dengan ketentuan Kovenan Liga BangsaBangsa dan Perserikatan Bangsa-Bangsa dan bahwa Palestina seharusnya berhak menentukan masa depan mereka. Keamanan dan ketertiban di Palestina telah terganggu. Agresi Zionis mengakibatkan eksodus lebih dari seperempat juta penduduk Palestina dari rumah mereka dan harus berlindung di negara-negara tetangga Arab (Israel Minister of Foreig Affair, 1947-1974).

Kebijakan terbaru tentang Palestina yang membuat reaksi dari negara-negara Arab adalah manuver politik Trump di Timur Tengah. Trump atas nama AS melakukan pengakuan terhadap Yerussalem. Pada 5 Desember 2017, negara-negara Arab yang tergabung dalam Liga Arab mengadakan pertemuan darurat 
di Kairo terkait pernyataan AS atas Yerussalem tersebut (Akim, 2018) (Wibowo, 2014). Hasil dari pertemuan darurat Liga Arab menegaskan bahwa keputusan AS tersebut ilegal karena merusak proses perdamaian, memperdalam ketegangan dan menimbulkan kemarahan. Mereka meminta AS untuk membatalkan keputusannya dan bekerja dengan komunitas internasional untuk mewajibkan Israel mengakhiri pendudukannya di Palestina melalui solusi damai yang menjamin pendirian negara Palestina dengan Yerusalem sebagai ibukotanya. Mereka juga mendesak Dewan Keamanan PBB untuk mengeluarkan resolusi yang menegaskan bahwa keputusan AS itu bertentangan dengan resolusi internasional (Egypt Today staff, 2017).

Di akhir 2020 ini, empat negara Arab yaitu Uni Emirat Arab, Bahrain, Sudan dan Maroko telah mendeklarasikan diri untuk menormalisasi hubungan mereka secara diplomatik dengan Israel. Adanya normalisasi hubungan ini tidak terlepas dari adanya dorongan dari Trump sebagai presiden AS. Hal tersebut menjadikan timbulnya tanda tanya baru. Keempat negara Arab yang baru melakukan normalisasi ini telah menyusul Mesir dan Yordania yang telah lebih dulu melakukan hal tersebut. Uni Emirat Arab melakukan normalisasi hubungannya dengan Israel pada tanggal 13 Agustus 2020 (Muhamad, 2020). Kemudian disusul Bahrain, dan pada tanggal 15 September 2020, Bahrain dan Uni Emirat Arab secara bersamaan menandatangani perjanjian di Gedung Putih, Washington DC. Sudan pada 23 Oktober 2020 menyetujui normalisasi hubungan dengan Israel (Nashrullah, 2020). Dan yang terakhir adalah Maroko melalui pernyataan Raja Mohammed VI pada 10 Desember 2020 (Wirawan, 2020).

Sementara itu, Trump mengklaim bahwa normalisasi hubungan yang ditengahi oleh AS ini sebagai kesepakatan poitik terhebat di dunia. Akan tetapi Palestina dan Iran mengeluarkan kutukukan dan menentang atas keputusan normalisasi hubungan beberapa negara Arab dengan Israel ini. Iran menganggap adanya normalisasi ini sebagai bentuk pengkhianatan negara Arab terhadap Palestina, menjual Islam sebagai kesepakatan kepentingan nasional semata (Kencana, 2020). Tak hanya itu, bantuan dari negara-negara Arab sebelumnya untuk Palestina turun drastis pada tahun 2020 . Dari tahun sebelumnya yang berjumlah sekita 267 juta dollar AS menjadi 38 juta dollar AS (Sicca, 2020). Kemudian Uni Emirat Arab juga memangkas bantuan kepada pengungsi Palestina melalui PBB 
dalam Badan Bantuan PBB untuk pengungsi Palestina ( UNRWA) yang sebelumnya berjumlah 51,7 juta dollar AS menjadi 1 juta dollar AS pada 2020 (S, 2021).

Tentunya normalisasi hubungan negara-negara anggota Liga Arab ini tidak mungkin dengan tangan kosong, dibuktikan dengan adanya alur perdagangan senjata sebagai pertimbangan penting dari kesepakatan normalisasi. Dengan menjadi sekutu Amerika, maka Uni Emirat Arab, Bahrain, serta Israel bisa mendapat akses bantuan pertahanan dari Amerika, dilihat pada data penjualan senjata pada 2019 (pra-normalisasi) perdagangan senjata Amerika Serikat sudah meningkat 42 persen atau setara US\$70 miliar (Rp990 triliun). Selain perdagangan senjata, keuntungan lain adalah diplomasi tradisional. Wakil Presiden dari lembaga Center for Strategic and International Studies, Jon Alterman, menyebut normalisasi hubungan antara Israel, Uni Emirat Arab, dan Bahrain akan menyederhanakan diplomasi di Timur Tengah (Sekarwati, 2020). Bagi Sudan adanya normalisasi ini berarti meredanya boikot AS terhadap negaranya yang dituduh sebagai pemasok senjata bagi kelompok teroris di Timur Tengah. Dan bagi Maroko, penawaran investasi, kerja sama bilateral dan permasalahan air merupakan penawaran yang cukup menjanjikan bagi negaranya (Pristiandaru, 2020). Tulisan ini menganalisa kepentingan-kepentingan dari negaranegara Arab di balik normalisasi hubungan dengan Israel. Mengapa pilihan normalisasi hubungan dengan Israel dianggap lebih penting daripada komitmen bersama untuk mewujudkan kemerdekaan Palestina.

\section{Kerangka Teori}

Teori Pilihan Rasional (Rational Choice)

Banyak perdebatan tentang teori pilihan rasional, dominasi keterkaitan teori ini banyak digunakan dalam analisa ekonomi pada awalnya. Namun, teori pilihan rasional lama kelamaan digunakan untuk melihat pola perilaku sosial sampai perspektif aktor hubungan intenasional. Teori pilihan rasional berpandangan tentang bagaimana sebuah keputusan itu dibuat untuk mencapai tujuan yang dipandang maksimal. Individu rasional adalah orang yang mampu secara tepat mendefinisikan masalah, menetapkan tujuan yang jelas dan menetapkan sekumpulan alternatif (pilihan) untuk mencapai tujuan (Pavličić, 2004). Teori pilihan rasional menafsirkan segala jenis perilaku dan setiap pilihan seolah-olah memaksimalkan utilitas pribadi, dimana utilitas pribadi dapat mencakup apa saja, 
mulai dari pertimbangan egoisme, hingga kepedulian terhadap orang lain dan masalah moral (Radovanović, 2019).

Rasional pilihan berpusat pada asumsi cost and benefit dimana memusatkan diri terhadap individu pemerintah untuk membuat keputusan pemerintahan yang berpandangan pada keuntungan dan kerugian yang akan didapat atas keputusan yang dibuat tersebut (Mas'oed, 1998). Keputusan yang dibuat berdasarkan teori pilihan rasional sebenarnya tidak terlepas dari kepentingan nasional suatu negara. Fungsi dari kepentingan nasional sendiri sebagai unsur landasan atau patokan para pemimpin dalam melakukan hubungan luar negeri dan untuk mengevaluasi kinerja pemerintah dalam melakukan interaksi di dunia internasional (Ronapea, 2016). Morgenthau berpendapat bahwa kepentingan nasional merupakan alat untuk mengejar kekuasaan, karena melalui kekuasaan itulah suatu negara dapat mengontrol negara lain dan untuk melindungi dan mempertahankan identitas fisik, politik, dan budaya dari gangguan negara lain (Morgenthau, 1985).

Jika dikaitkan dengan hal yang dilakukan negara-negara Arab, normalisasi hubungan dengan Israel yang selama puluhan tahun telah menjadi daftar hitam yang dihindari untuk melakukan hubungan diplomatik tentu saja hal tersebut menjadi pilihan yang cukup rumit untuk dipertimbangkan negara-negara Arab. Persfektif ekonomi cenderung sangat kuat terlihat dari hasil kesepakatan normalisasi yang ditandatangani keempat negara Arab tersebut untuk menormalisasi hubungan dengan Israel. Maka dari itu, analisa tulisan ini berlandaskan teori pilihan rasional akan membantu meperlihatkan bagaimana sebuah keputusan negara itu bekerja dengan mementingkan untung dan rugi yang diterima.

\section{Metode Penelitian}

Dalam penelitian ini penulis menggunakan metode kualitatif bersifat menekankan pada pemahaman mengenai masalah kehidupan sosial berdasarkan kondisi realitas yang subyektif dan berdimensi banyak (Jatmika, 2016). Analisanya berdasarkan data-data valid bersumber dari buku, jurnal, dan beritaberita online melalui website terpercaya. Diawali dengan mengumpulkan fakta fakta dari objek yang berkaitan kemudian fakta - fakta tersebut diubah menjadi general empiris, dan kemudian melalui general empiris dapat dilakukan perumusan konsep, merangkai preposisi dan diubah untuk menjadi induksi teori (Mochtar, 1990). 


\section{Data tersebut dijadikan sebagai} bahan telaahan oleh penulis untuk mengamati dan mendapatkan pembahasan serta kesimpulan dari tulisan ini. Objek dalam tulisan ini merupakan negara-negara di kawasan Timur Tengah yang sebelumnya tidak memiliki hubungan yang terlalu harmonis akan tetapi di tahun 2020 ini beberapa negara Arab seolah berputar haluan untuk menormalisasi hubungan mereka, oleh karena itu data berdasarkan sumber bacaan sebelum di tahun-tahun sebelumnya dan sekarang dapat menjadi sumber telaahan untuk menuai hasil dari tulisan ini.

\section{Pembahasan}

\section{Hubungan Israel dengan Negara- Negara Arab}

Hubungan Israel dengan negaranegara Arab telah mengalami masa bersitegang selama puluhan tahun. Sengketa Arab-Israel menjadi permasalahan utama. Sengketa ini melibatkan benturan dua gerakan nasional, Yahudi dan Arab (Marmor, 1963). Ideologi zionisme yang dapat didefinisikan sebagai kepercayaan akan kembalinya para diaspora yahudi setelah sekian lama untuk menyelamatkan kaum yagudi dari pemerintahan non-yahudi. Tujuan dari zionis ini adalah mendirikan negara yahudi. Untuk mewujudkan negara-bangsa
Yahudi, dilakukan adanya pencarian tanah air yang disebut sebagai "Promised Land" yang pertama kali dirumuskan oleh mantan wartawan Theodore Hertzl pada tahun 1897. Kawasan yang dicari kaun yahudi ini melalui proses yang panjang mulai dari Amerika Selatan, Afrika, sampai kemudian kaum zionis yahudi menetapkan Palestina sebagai "Promised Land" (Azyumardi, 2002). Kemudian, adanya kebijakan Tsar Rusia yang anti yahudi, mendorong migrasi besar-besaran kaum yahudi ke Palestina 1882 hingg 1918. Gelombang migrasi ini menyebabkan pergeseran besar terhadap kaum yahudi terutama di wilayah Palestina. Pergeseran kekuasaan dinasti Usmani pada masa akhir abad ke-19 dan kondisi ekonomi penduduk Palestina yang miskin membuat mereka menjual tanahnya-tanahnya kepada kaun yahudi hal ini juga menjadi faktor utama kemudahan bagi masuknya kaum yahudi ini (Abidin, 2016 ).

Kemudian Inggris menaklukkan Palestina dari Turki Ottoman pada tahun 1917-1918, mengeluarkan Deklarasi Balfour yang menjanjikan kemerdekaan terhadap yahudi dengan memberikan wilayah Palestina dan hal tersebut membuat kaum yahudi semakin mendorong migrasi besar-besaran kaumnya ke Palestina. Inggris memerintah Palestina selama tiga puluh tahun dengan 
mandat dari Liga Bangsa-Bangsa pada tahun 1922 (Morris, 2014). Kemudian Israel mendeklarasikan kemerdekaanya pada 14 Mei 1948 tepat setelah berakhirnya mandat dari Liga BangsaBangsa terhadap Inggris, hal tersebut memicu perang sipil pada 15 Mei 1948 dimana tentara dari Lebanon, Irak, Mesir, Yordania, Suriah dan tentara Arab lainnya menyerang Israel. Peperangan ini dimenangkan oleh Israel dengan mendapatkan $70 \%$ dari wilayah yang diperebutkan dari mandat PBB (Wong, 2020). Dari sanalah perjalanan konflik antara bangsa Arab yang mendukung Palestina untuk menjadi negara berdaulat dengan wilayah yang diinginkan Israel ini berkecamuk.

Penyebab utama pemberontakan Arab adalah imigrasi besar-besaran orang Yahudi ke Palestina dari Eropa Timur dan Tengah, gelombang demografis yang mengancam di mata Arab untuk mengubah tanah Arab menjadi negara Yahudi dan mungkin juga mengusir orang-orang Arab (Morris, 2014). Berbagai macam perdamaian telah coba dilakukan dalam perjalanan konflik ini, seperti munculnya kesepakatan Oslo pada 1993 yaitu perjanjian untuk kemerdekaan Palestina, Kesepakatan Oslo menandai pertama kalinya Israel dan Organisasi Pembebasan Palestina (PLO) yang merupakan lembaga politik resmi Arab Palestina yang telah diakui dunia internasional secara resmi saling mengakui kebedaraan negara mereka masing-masing, akan tetapi perjanjian ini diingkari oleh Israel. Adanya keingkaran terhadap perjanjian membuat peduduk Palestina melakukan perlawanan dengan Intifada (melempar batu). Hal tersebut sempat dihentikan dengan penawaran atas perjanjian, namun hal tersebut lagi-lagi tidak pernah ditepati (Armando Christofel Wirajaya, 2020).

Sebenarnya jika dilihat secara total dari keanggotaan Perserikatan BangsaBangsa (PBB) saat ini yang berjumlah 193 negara, 30 negara tidak mengakui adanya Israel, negara-negara tersebut adalah negara-negara Timur Tengah, dan negara mayoritas muslim termasuk Indonesia, Malaysia, Pakistan dan negara-negara yang tergabung di dalam Organisasi Kerjasama Islam (OKI) (Bonasir, 2020). Selama puluhan tahun negara-negara Arab tampaknya konsisten dengan terhadap Palestina dengan menutup pintu diplomatik mereka dari Israel, kecuali normalisasi hubungan yang dilakukan Mesir pada 1979 meski pernah terlibat perang Arab Israel 1948 dan perang Yom Kippur 1973. Perdamaian Mesir ini bahkan direspon Liga Arab dengan mengucilkan Mesir dan memindahkan pusat KTT liga Arab dari Kairo. Kemudian 
Yordania yang menandatangani perjanjian damai pada tahun 1994 meski sebelumnya pernah terlibat dalam Perang 6 Hari melawan Israel pada 1967 (Setyaningrum, 2020). Akan tetapi dunia seolah dapat meredam normalisasi kedua negara ini, kerena hubungan Mesir, Yordania dengan Israel juga kerap tegang dengan adanya krisis di sekitar Al-Aqsa. Namun, rekor terbaru perubahan dinamika hubungan Israel dengan Negara-negara Arab ada pada tahun 2020 ini dimana negara-negara Arab yaitu Uni Emirat Arab, Bahrain, Sudan dan Maroko bersedia melakukan normalisasi dengan Israel. Hal ini akan menjadi babak baru dalam perjalanan resolusi damai hubungan antara bangsa Arab dan Yahudi yang di klaim oleh AS.

Campur Tangan AS dalam Kesepakatan Normalisasi

Bukanlah sebuah rahasia bila AS memiliki keberpihakan terhadap Israel terutama pada masa pemerintahan Donald Trump. Pada awal kampanye pemilihan presiden 2016, keadaan hubungan bilateral antara AS dan Israel sering dianggapnya rusak akibat keputusan pemerintahan Obama untuk melakukan negosiasi dengan Iran dan abstain untuk memveto Resolusi Dewan Keamanan PBB 2334 (Samarskaia, 2020). Pada pemerintahan Trump manuver politiknya di Timur Tengah menjadikan banyak keuntungan bagi Israel. Trump atas nama AS melakukan pengakuan terhadap Yerussalem yang menyebabkan timbulnya berbagai kecaman terutama dari negaranegara Arab. Pada 5 Desember 2017, negara-negara Arab yang tergabung dalam Liga Arab mengadakan pertemuan darurat di Kairo terkait pernyataan AS atas Yerussalem dan hasil dari pertemuan tersebut yaitu penolakan atas klaim AS dan meminta adanya resolusi dari $\mathrm{PBB}$ atas kelanjutan pernyataan Trump tersebut (Akim, 2018).

Selain mengakui kedaulatan Israel atas Dataran Tinggi Golan, Trump juga mendukung pemukiman Israel di Tepi Barat, wilayah yang dicari Palestina untuk dijadikan kedaulatannya menjadi sebuah negara. Investasi Israel di permukiman Tepi Barat berdasarkan data resmi Israel yang diberikan kepada Departemen Luar Negeri AS antara 2017 hingga 2019 meningkat hampir setengahnya dibandingkan tiga tahun terakhir di kepemimpinan Obama. Sehari sebelum pelantikan Biden pada Januari 2021, Israel mengeluarkan tender untuk lebih dari 2.500 rumah permukiman di Tepi Barat dan Yerussalem Timur yang diduduki, di atas ratusan lainnya yang diumumkan oleh Netanyahu. Dan Hubungan dengan Palestina mencapai titik terendah baru, setelah Trump memotong \$ 360 juta dana 
tahunan untuk The United Nation Relief and Work Agency (UNRWA) badan Perserikatan Bangsa-Bangsa yang menangani pengungsi Palestina, mengurangi bantuan lain untuk Palestina, dan menutup kantor Organisasi Pembebasan Palestina di Washington DC (Ayyub, 2021). Donald Trump konsisten dalam posisinya yang benar-benar antikritis dan pro-Israel, mewujudkan semua janji awalnya mengenai negara Yahudi. Pada akhir masa jabatannya, ia secara signifikan mengubah kerangka kerja kebijakan tradisional Amerika yang sudah mapan ke Israel termasuk dalam bentuk adanya normalisasi negara-negara Arab dengan Israel (Samarskaia, 2020).

\section{"Abraham Accords" nama} perjanjian kesepakatan normalisasi yang ditengahi oleh pemerintahan Trump, kesepakatan itu melanggar konsensus bertahun-tahun di antara sebagian besar negara Arab yang mengatakan bahwa pengakuan resmi apa pun atas Israel bergantung pada akhir pendudukan wilayah Palestina dan pembentukan solusi dua negara di perbatasan tahun 1967. Sebelum Agustus, hanya dua negara Arab yang memiliki hubungan resmi dengan Israel, Mesir pada 1979 dan Yordania pada 1994 (Zvulun, 2020). Trump mengklaim hal ini merupakan kesepakatan politik terhebat di dunia. Dikutip dari website New York Times tentang pernyataan Donal Trump atas normalisasi negaranegara Arab dengan Israel ini, "This deal is a significant step towards building a more peaceful, secure and prosperous Middle East," (Peter Baker, 2020).

Adanya normalisasi ini tentunya juga memiliki pertimbangan bukan hanya sekadar untuk mendukung Israel. Dari segi strategi hegemoni AS, adanya normalisasi ini dapat membantu AS memberikan lagi "Maximum Treasure" terhadap Iran. Trump melakukan penarikan diri dari perjanjian nuklir Iran dengan tujuan untuk membawa kembali Iran ke meja perundingan kesepakatan nuklir tersebut. Kesepakatan itu tidak mencegah Iran untuk membangun senjata nuklir dan dalam beberapa hal sebenarnya memudahkan Iran untuk menggunakan nuklir di masa depan. Menurut Trump kelanjutan dari kesepakatan saat ini dapat merusak kepentingan Amerika di Timur Tengah dan kebijakan non-proliferasi globalnya (Kroenig, 2018). Namun diketahui 2 tahun setelah kebijakan tersebut AS belum mampu menuai hasil yang diinginkan (Hamidreza Azizi, 2020). Adanya normalisasi Israel dengan negaranegara Arab ini akan menjadikan mereka sekutu baru bagi AS, karena kita ketahui 
bahwa negara-negara Arab yang melakukan normalisasi dengan Israel memiliki hubungan yang juga kurang harmonis dengan Iran sehingga hal tersebut dapat menyempitkan ruang gerak Iran terutama diwilayah yang bertasan langsung seperti Uni Emirat Arab.

\section{Keuntungan Uni Emirat Arab, Bahrain,}

\section{Sudan dan Maroko atas Normalisasi}

Normalisasi hubungan Uni Emirat

Arab, Bahrain, Sudan dan Maroko dengan Israel merupakan peristiwa yang mengandung polemik. Keadaan seolah berubah bagi Palestina, angan-angan kemerdekaan Palestina secara berdaulat dan memiliki wilayah sendiri menjadi semakin panjang. Negara-negara Arab merupakan beberapa pendukung terkuat untuk bertahannya Palestina hingga saat ini, bukan hanya tentang dukungan sisi materi seperti, ekonomi, kesehatan, militer akan tetapi secara psikologis dan geografis. Adanya nomalisasi hubungan antara beberapa negara Arab dengan Israel seperti sebuah pengkhianatan apalagi ditambah juga dengan turunnya angka bantuan yang sampai ke Palestina seiring dengan trealisasinya normalisasi negaranegara Arab ini. Lalu apa yang diterima oleh negara-negara Arab sehingga mampu meruntuhkan tembok batasan hubungan dengan Israel? Negara-negara Arab yang melakukan normalisasi berasumsi bahwa apa yang mereka lakukan bagian dari pilihan yang cukup rasional untuk mengadapi konflik Israel-Palestina dan kepetingan negara mereka saat ini.

Uni Emirat Arab dan Bahrain

Kepentingan yang sama dimiliki oleh Uni Emirat Arab, Bahrain dan Israel adalah dalam politik keamanan dan ekonomi (Wicaksono, 2020). Perjanjian dengan UEA dan Bahrain, negara kaya minyak dengan pengaruh kawasan yang cukup besar, dipandang sebagai terobosan bersejarah yang dapat mengubah kawasan tersebut.bagi Uni Emirat Arab dan Israel, mereka telah sepakat untuk mengesampingkan persyaratan visa untuk warga negara masing-masing dan menandatangani sejumlah perjanjian bilateral tentang investasi, pariwisata, penerbangan langsung, keamanan, dan telekomunikasi. UEA memiliki target untuk memperoleh jet tempur F-35 buatan AS, yang berpotensi menggeser keseimbangan kekuatan di wilayah tersebut. Israel adalah satu-satunya negara di kawasan yang memiliki F-35 tetapi menolak penjualan mereka ke UEA setelah mengatakan AS telah meyakinkannya bahwa superioritas militer Israel akan dipertahankan (Zvulun, 2020).

Menormalisasi hubungan dengan Israel, itu menandakan Uni Emirat Arab, 
Bahrain menjadi sekutu Amerika dan bisa mendapat akses bantuan pertahanan dari Amerika, dilihat pada data penjualan senjata pada 2019 (pra-normalisasi) perdagangan senjata Amerika Serikat sudah meningkat 42 persen atau setara US\$70 miliar (Rp990 triliun) (Sekarwati, 2020).Sehari sebelum pelantikan Joe Biden, Kedutaan Besar UEA di Washintone DC melalui websitenya menyatakan telah menandatangani perjanjian terkait pembelian 18 unit drone dan 50 unit pesawat jet tempur F-35 (Jamil, 2021). Selain perdagangan senjata, keuntungan lain adalah diplomasi tradisional. Wakil Presiden dari lembaga Center for Strategic and International Studies, Jon Alterman, menyebut normalisasi hubungan antara Israel, Uni Emirat Arab, dan Bahrain akan menyederhanakan diplomasi di Timur Tengah (Sekarwati, 2020). Dan hal tersebut dapat juga menjadi ladang bisnis lain di UEA dan Bahrain, sebagai wisata gurun, pantai dan pusat perbelanjaan yang diincar turis dari Israel. Hal tersebut tampaknya akan berjalan cukup mulus dengan rencana membukaan jalur penerbangan langsung dari negara-negara tersebut. Salah satunya telah dikonfirmasi yaitu maskapai nasional milik UEA yaitu Etihad Airway yang akan membuka penerbangan pada Maret 2021 (J, 2020).
Melalui menteri dalam negerinya Bahrain beralasan bahwa melakukan normalisasi dengan Israel merupakan bagian dari melindungi kepentingan negaranya (Firmansyah, 2020). Sementara menurut pendapat Vision Center for Political Development, kehadiran kuat Iran di Irak, Suriah, dan Yaman meningkatkan kebutuhan negara-negara Teluk Arab terhadap dukungan dan perlindungan AS (Mohammed al-Ragawi, 2021). Penguatan hubungan dengan AS dan memperoleh beberapa sistem keamanan dan militer Israel, atau memiliki teman atau sekutu di kawasan untuk membantu mereka menghadapi potensi risiko yang ditimbulkan dari pengaruh Iran (Hamidreza Azizi, 2020).

\section{Sudan}

Keputusan Sudan untuk menormalisasi hubungan dengan Israel telah menuai kecaman luas dari partai politik di dalam negeri. Sudan tengah berada pada masa transisi pemerintahan. Kritikan yang diarahkan ke Sudan tentang pemerintah transisi yang harusnya tidak memiliki hak untuk mengambil keputusan menormalisasi hubungan dengan Israel (Arab Center for Research and Policy Studies, 2016). Setelah bertahun-tahun mencoba untuk bekerja sama dengan Amerika Serikat, dan bahkan 
penyerahan akhirnya ke Selatan, semua upaya Khartoum untuk mencabut sanksi AS telah sia-sia (Shane, 2005).

Diketahui bahwa Sudan masuk dalam daftar negara yang mendukung terrorisme. Penting bagi Sudan untuk mengambil langkah menghilangkan tuduhan AS ini akan dapat berkembang secara ekonomi melalui investasi, bantuan dan pinjaman luar negeri. Sudah diketahui mengalami keterpurukan ekonomi setelah namanya tercantum dalam daftar tersebut (Aini, 2020). Khartoum menandatangani kesepakatan yang disponsori AS untuk menormalkan hubungan dengan Israel, Washington menandatangani nota kesepahaman dengan Sudan untuk membayar \$ 1 miliar dari tunggakan Sudan ke Bank Dunia. Sudan akan mendapatkan banyak keuntungan ekonomi internasional. Hal tersebut akan menciptakan peluang positif yang signifikan bagi Sudan dalam membuka sejumlah besar dana baik di Bank Dunia, IMF, dan di Amerika Serikat. Sementara itu, Menteri Kehakiman Sudan Nasur Aldin Abdul Bari, yang menandatangani kesepakatan itu, mengatakan bahwa Sudan sangat ingin melangkah lebih jauh dalam membangun hubungan diplomatik dengan Israel (Mohammed al-Ragawi, 2021). diketahui akan memberikan bantuan dana sebesar 750 juta dollar AS dan memberikan paket bantuan selama 2 tahun dalam bentuk gandum dan obat-obatan, serta bahan bakar. Meski begitu adanya normalisasi hubungan antara Sudan dan Israel ini telah membelah Sudah menjadi dua bagian dimana, partai sayap kiri, Sudanese Congress Party dan Sudanese National Alliance, serta kelompok pemberontak Sudan Liberation Movement menyambut baik kesepakatan itu. Sementara partai sayap moderat Islam, National Umma Party (NUP) dan Partai Komunis Sudan menolak keras kesepakatan normalisasi (Aini, 2020).

\section{Maroko dan Sahara Barat}

Hubungan diplomatik resmi antara Maroko dan Israel dimulai pada tahun 1994 pada tingkat yang rendah. Tetapi Rabat membekukan hubungan dengan Tel Aviv pada tahun 2000, setelah pecahnya intifada Palestina kedua. Bahkan sebelum pengakuan resmi, hubungan antara kedua negara telah diperpanjang hingga beberapa dekade terakhir, menyaksikan imigrasi orang Yahudi Maroko ke Israel dan pertemuan antara pejabat dari kedua negara. Itu juga termasuk pertemuan antara Raja Maroko dan Perdana Menteri Israel. 
Maroko dan Israel setuju untuk menormalisasi hubungan dalam kesepakatan yang ditengahi dengan bantuan AS pada bulan Desember. Sebagai bagian dari kesepakatan itu, AS mengakui kedaulatan Maroko atas Sahara Barat, wilayah sengketa yang diklaim oleh Rabat dan front Polisario yang didukung Aljazair. Maroko beranggapan langkah tersebut bukan normalisasi, melainkan dimulainya kembali hubungan resmi yang dimulai pada 1993 tetapi dihentikan pada 2000 (Welle, 2020).

Abdel Fattah El-Fatihi, kepala Pusat Strategis Sahara dan Afrika yang berbasis di Rabat, mengatakan normalisasi Maroko dengan Israel terjadi karena berbagai alasan, termasuk posisinya di wilayah Sahara. Normalisasi Maroko dengan Israel karena beberapa alasan, termasuk tertarik untuk memperkuat kembali hubungannya dengan warga Yahudi, yang berjumlah lebih dari 1,5 juta warga Yahudi Maroko diisraelkan menghidupkan kembali. Aktivitas pariwisata Maroko setelah pandemi virus covid19. Serta apa yang diusahakan untuk mendapatkan keuntungan dari keunggulan teknologi dari Israel untuk proyek-proyek pembangunan di Maroko (Mohammed alRagawi, 2021).
Dari Segi Politik memanfaatkan hubungannya dengan Israel - diharapkan memainkan peran yang kuat dalam dialog Palestina-Israel. Untuk melanjutkan hubungan diplomatik Maroko dengan Israel, Maroko akan memperkuat posisi negosiasinya di Sahara, dan ini akan diperkuat oleh mobilisasi Amerika sekutunya untuk pengakuan internasional atas Sahara Maroko. Dimana kawasan tersebut juga akan menjadi tujuan proyek investasi penting AS serta memperkuat kerja sama militer dan keamanan antara Maroko dan AS.

\section{Kesimpulan}

Hubungan negara-negara Arab dengan Israel sebelumnya dibatasi oleh tembok secara tak kasat mata. Adanya faktor perbedaan ideologi antara Islam dan Yahudi serta sejarah kolonialisme terdahulu menjadikan pemetaan konflik antara Islam dan Yahudi di Timur Tengah ini belum juga usai. Namun, krisis hubungan yang dihadapi oleh negaranegara Arab dan Israel mungkin akan memasuki babak baru. Keharmonisan yang mulai terjalin karena adanya kesepakatan Abraham Accords didorong oleh Amerika Serikat dengan penawaran-penawaran yang cukup menggiurkan. Uni Emirat, Bahrain, Sudan dan Maroko mengklaim apa yang mereka lakukan merupakan aksi 
rasionalitas baru demi keberlangsungan kepentingan negara mereka dan masa depan Palestina. Ditangguhkannya pencaplokan tepi barat oleh Israel menjadi salah satu syarat dari normalisasi ini, akan tetapi perlu kita ketahui bukan berarti, Israel akan menyerah begitu saja pada masa mendatang kepada tepi barat.

Secara garis besar kepentingan akan ancaman keamanan dan ekonomi, menjadi rasionalitas nasional yang lebih dipertimbangkan oleh negara-negara Arab. Keinginan untuk meningkatkan stabilitas keamanan Uni Emirat Arab, Bahrain, dan Israel dari ancaman Iran membuat posisi mereka harus siap berpihak terhadap salah satu sekutu yang layak seperti Amerika Serikat. Pengakuan AS atas Sahara Barat untuk Maroko akan menekan posisi Rabat dan front Polisario yang didukung Aljazair. Pengahapusan Sudan dari daftar hitam negara yang mendukung terorisme akan memberikan peluang ekonomi baru dan ruang gerak Sudan dalam lingkup internasional. Meskipun demikian, tidak dapat dipungkiri bahwa kebijkan normalisasi ini adalah dorongan dari seorang aktor yaitu Donald Trump yang mungkin saja dapat berbanding terbalik ketika Amerika Serikat yang kini tengah merancang masa depan bersama Joe Biden.

\section{Referensi}

Buku

Azyumardi, A. (2002). Konflik Baru Antar Peradaban, Globalisasi, Radikalisme, dan Pluralitas. Jakarta: PT. Raja Grafindi Persanda.

Bandoro, B. (1991). Timur Tengah Pasca Perang teluk: Dimensi Internal dan Eksternal. Jakarta: CSIS.

Bixby, A. (1992). Timur Tengah di Tengah Kancah Dunia. Bandung: Sinar Baru Algensindo.

Jatmika, S. (2016). Skripsi : Metodologi dan Romantikanya. Yogyakarta: Penerbit Samudra Biru.

Mochtar, M. (1990). Ilmu Hubungan Internasional:Disiplin dan Metodologi. Yogyakarta: LP3ES.

Morgenthau, H. J. (1985). Politic Among Nation, The Struggle for Power and Peace (Sixth Edition). New York: Knopf:distributed by Random House.

Mas'oed, M. (1998). Persfektif Ekonomi Politik Dalam Studi Hubungan Internasional. Yogyakarta: UGM.

Pavličić, D. (2004). Decision Theory. Ekonomski fakultet Univerziteta $u$ Beogradu - Centar za izdavačku delatnost.

Jurnal

Abidin, A. S. (2016 ). Sejarah Zionisme dan Berdirinya Negara Israel. Jurnal Adabiyah Vol.16, 172-185.

Akim, F. R. (2018). Klaim Sepihak Donald Trump terhadap Kota 
Yerusalem sebagai Ibu Kota Israel dalam PerspektifKonstruktivisme. Jurnal Universitas Parahyangan, 20-30.

Armando Christofel Wirajaya, M. G. (2020). Penyelesaian Sengketa Palestina dan Israel Menurut Hukum Internasional (Studi Kasus Perampasan Wilayah Palestina di Israel). Lex Et Societatis Vol. VIII/, 45-52.

Hamidreza Azizi, V. G. (2020). Trump's "Maximum Treasure" and AntiContaiment in Iran Regional Policy . Digest of Middle East Studies, Policy Studies Organization Published by Wiley Periodicals, Inc., 1-17.

Kroenig, M. (2018). The Return to The Presurre Track: The Trump Administration and The Iran Nuclear Deal . Diplomacy and Statecraft, 2-11.

Marmor, D. (1963). Israel and the Middle East. The Journal of Educational Sociology, Vol. 36, 377-379.

Masyrofah. (2015). Fakta Perjanjian Damai Hubunga Diplomatik Negara Timur Tengah dalam Proses Perdamaian Konflik IsraelPalestina Pasca Kemerdekaan Palestina. Fakultas Syariah dan Hukum UIN Syarif Hidayatullah, 82-102.

Morris, B. (2014). Reviewed Work(s):

Britain's Moment in Palestine: Retrospect and Perspectives, 19171948 by Michael J. Cohen: The Arab Revolt in Palestine, 1936-
1939 by Yuval Arnon-Ohana. The Middle East Book Review, Vol. 5, 136-145.

Muhamad, S. V. (2020). Normalisasi Hubungan Uni Emirat Arab-Israel dan Isu Palestina. Kajian Singkat Terhadap Isu Aktual dan Startegis Vol.XII, 7-12.

Printina, B. I. (2019). Analisa Potensi Geografis Timur Tengah Menjadi kekuatan Teritori Melalui Komik Digital Berlandaskan Pedagodi Reflektif. Jurnal Agastya Vol.9, 45-46.

Radovanović, B. S. (2019). Rational Choice Theory And Charitable Giving. Sociološki pregled / Sociological Review, vol. LIII no. 2, , pp. 445-466.

Samarskaia, A. D. (2020). The U.S. Israel "special relations": Structural foundations and trump factor. World Economy and International Relations Vol.64 Issues 10, 40-51.

Wibowo, H. (2014). Mandat Liga BangsaBangsa : Kegagalan Palestina Menjadi Negara Merdeka (19201948). Al-Turas Vol. XX, No. 2 , 279-309.

Wicaksono, R. M. (2020). Analisis Kebijakan Uni Emirat Arab dalam Normalisasi Hubungannya dengan Israel. Jurnal Middle East and Islamic Studies, Volume 7 No. 2 , 132-154.

Website 
Aini, N. (2020, Oktober 26). Normalisasi Hubungan Sudan-Israel Pecah Negeri 2 Nil. Diakses melalui Republika.co.id: https://republika.co.id/berita/qisp5d 382/normalisasi-hubungansudanisrael-pecah-negeri-2-nil

Arab Center for Research and Policy Studies. (2016). A Normalization of Sudan-Israel Relations: Why Not? Doha: Arab Center for Research and Policy Studies.

Ayyub, M. L. (2021, Januari 20). Analysis: What will survive of U.S.-Middle East policy under Biden? Diakses melalui Reuters.com: https://www.reuters.com/article/ususa-trump-legacy-mideast-analysisidUSKBN29P1RB

Bonasir, R. (2020, September 17). Konflik Timur Tengah: Normalisasi hubungan Israel-negara-negara Teluk menjadi pintu masuk bagi Indonesia. Diakses melalui BBC News: https://www.bbc.com/indonesia/du nia-54177712

Coskun, T. (2020, 2020). The History of the Arab League. Diakses melalui www.unict.it: https://www.google.com/search?sa $\mathrm{fe}=$ strict\&client $=$ firefox $-\mathrm{b}-$ $\mathrm{d} \&$ sxsrf=ALeKk00HQuimfrdf88t6 Ke0v_1K4Va_fig\%3A1612934885 456\&ei=5W4jYJKoG_KLmgfXuL zwCg\&q=Coskun+Tumer+the+hist ory+of+arab+league\&oq=Coskun+ Tumer+the+history+of+arab+leagu e\&gs_lcp=CgZwc3ktYWIQAzoK $\mathrm{CCM}$
Egypt Today staff. (2017, Desember 10 ). Arab FMs call on UNSC to recognize US decision as contradictory to international law. Diakses melalui Egypt Today: https://www.egypttoday.com/Articl e/1/36301/Arab-FMs-call-onUNSC-to-recognize-US-decisionas

Firmansyah, R. J. (2020, September 15). Bahrain: Normalisasi dengan Israel Lindungi Kepentingan Negara. Diakses melalui Republika.co.id: https://republika.co.id/berita/qgp0x 8377/bahrain-normalisasi-denganisrael-lindungi-kepentingan-nega

Israel Minister of Foreig Affair. (19471974). 5 Arab League declaration on the invasion of Palestine- 15 May 1948. Diakses melalui mfa.gov.il: https://mfa.gov.il/mfa/foreignpolic y/mfadocuments/yearbook1/pages/ 5\%20arab\%20league\%20declaratio $\mathrm{n} \% 20$ on\%20the \%20invasion\%20 of $\%$ 20pales.aspx

J, A. I. (2020, November 16). Maskapai UEA Etihad Airways Buka Penerbangan Langsung ke Israel Maret 2021. Diakses melalui Inews.id: https://www.inews.id/news/interna sional/maskapai-uea-etihadairways-buka-penerbanganlangsung-ke-israel-maret-2021

Jamil, A. I. (2021, Januari 23). Sehari Sebelum Lengser, Donald Trump Ternyata Lakukan Ini kepada Negara Arab. Diakses melalui 
Inew.id:

https://www.inews.id/news/interna sional/sehari-sebelum-lengserdonald-trump-ternyata-lakukan-inikepada-negara-arab

Kencana, M. (2020, Desember 12). Iran Sebut Normalisasi Maroko-Israel sebagai Pengkhianatan terhadap Islam. Diakses melalui

Kompas.com: https://www.kompas.com/global/re ad/2020/12/12/222523770/iransebut-normalisasi-maroko-israelsebagai-pengkhianatan-terhadapislam

Mohammed al-Ragawi, M. A. (2021, Januari 01). How US bribed Arab states to normalize ties with Israel. Diakses melalui AA News Broadcasting System: https://www.aa.com.tr/en/politics/h ow-us-bribed-arab-states-tonormalize-ties-with-israel/2108054

Nashrullah, N. (2020, November 02). Normalisasi Sudan dan Arab dengan Israel, Nasib Palestina? Diakses melalui Republika.co.id: https://republika.co.id/berita/qj67b w320/normalisasi-sudan-dan-arabdengan-israel-nasib-palestina

Peter Baker, I. K. (2020, Agustus 13). Israel and United Arab Emirates Strike Major Diplomatic Agreement. Diakses melalui New York Times:

https://www.nytimes.com/2020/08/ 13/us/politics/trump-israel-unitedarab-emirates-uae.html
Pristiandaru, D. L. (2020, Desember 23). Damai dengan Maroko, Israel Kirim Delegasi Perdana ke Rabat. Diakses melalui Kompas.com: https://www.kompas.com/global/re ad/2020/12/23/061643970/damaidengan-maroko-israel-kirimdelegasi-perdana-ke-rabat?page=all

Ronapea. (2016, November 21). Konsep Kepentingan Nasional dalam Hubungan Internasional. Diakses melalui unair.ac.id: http://ronapeafisip16.web.unair.ac.id/artikel_deta il-165107-

JURNAL\%2520SOH\%2520101KONSEP\%2520KEPENTINGAN $\% 2520$ NASIONAL $\% 2520$ DALA M\%2520HUBUNGAN\%2520INT ERNASIONAL.html

S, S. P. (2021, Februari 07). UEA Pangkas Drastis Bantuan ke Palestina Sebesar Rp 726,7 Miliar pada 2020. Diakses melalui

Kompas.com: https://www.kompas.com/global/re $\mathrm{ad} / 2021 / 02 / 07 / 112557470 /$ ueapangkas-drastis-bantuan-kepalestina-sebesar-rp-7267-miliarpada-2020

Sekarwati, S. (2020, Desember 23). Kaleidoskop 2020: Ramai-ramai Normalisasi Hubungan Israel . Diakses melalui Tempo.co: https://dunia.tempo.co/read/141516 3/kaleidoskop-2020-ramai-ramainormalisasi-hubunganisrael/full\&view $=$ ok

Setyaningrum, P. M. (2020, September 15). 4 Negara Arab dalam Pelukan Israel. Diakses melalui 
Wartaekonomi.co.id: https://www.wartaekonomi.co.id/re ad303899/4-negara-arab-dalampelukan-israel

Shane, S. (2005, Juni 18). C.I.A. Role in Visit of Sudan Intelligence Chief Causes Dispute Within Administration. Diakses melalui New York Times.

Sicca, S. P. (2020, September 25). Dana Bantuan Semakin Turun, Pejabat Palestina Khawatir Itu Akibat Perjanjian Damai Negara ArabIsrael. Diakses melalui Kompas.com: https://www.kompas.com/global/re ad/2020/09/25/213945070/danabantuan-semakin-turun-pejabatpalestina-khawatir-itu-akibat

Welle, D. (2020, Desember 12). Giliran Maroko Sepakati Normalisasi Hubungan dengan Israel. Diakses melalui Republika.com: ttps://republika.co.id/berita/ql6eve9 815000/giliran-maroko-sepakatinormalisasi-hubungan-denganisrael

Wirawan, M. K. (2020, Desember 11). Maroko Sepakati Normalisasi dengan Israel, Trump: Sebuah Terobosan Besar. Diakses melalui Kompas.com: https://www.kompas.com/global/re $\mathrm{ad} / 2020 / 12 / 11 / 185431370 /$ marokosepakati-normalisasi-dengan-israeltrump-sebuah-terobosanbesar?page $=$ all

Wong, A. (2020, September 16). Jejak Konflik Israel-Arab hingga
Berujung Aksi Normalisasi. Diakses melalui CNN News: https://www.cnnindonesia.com/inte rnasional/20200916163507-120547305/jejak-konflik-israel-arabhingga-berujung-aksi-normalisasi

Zvulun, L. R. (2020, November 23). Arab normalisation with Israel in 500 words. Diakses melalui Al-Jazeera: https://www.aljazeera.com/news/20 20/11/23/the-normalisation-of-tiesbetween-israel-and-arab-countries 